\title{
Oxidation of Ammonia by Methane-oxidizing Bacteria and the Effects of Ammonia on Methane Oxidation
}

\author{
By J. G. O'NEILL* AND J. F. WILKINSON \\ Department of General Microbiology, Edinburgh University, \\ Kings Buildings, Edinburgh EH9 $3 \mathrm{JG}$
}

(Received 3 January 1977)

\section{INTRODUCTION}

Certain similarities between methane-oxidizing bacteria and ammonia-oxidizing bacteria suggest an evolutionary relationship (Wilkinson, 1971; Quayle, 1972), but the interactions of methane-oxidizing bacteria with ammonia have only briefly been described. Hutton \& Zobell (1949) and Whittenbury, Phillips \& Wilkinson (1970) observed that methaneoxidizing bacteria produced nitrite from ammonia, and the latter workers also noted the competitive inhibition of methane utilization by ammonia. Recently Ferenci, Strøm \& Quayle (I975) showed that ammonia could act as a competitive inhibitor for both methane and carbon monoxide oxidation in Pseudomonas methanica. In addition Hubley, Thomson \& Wilkinson (1975) reported that the specificity of a number of inhibitors of ammonia oxidation in Nitrosomonas, as described by Hooper \& Terry (1973), followed a similar pattern when inhibiting methane oxidation in Methylosinus trichosporium.

This work attempts to describe more precisely the nature of the interactions of ammonia with methane-oxidizing bacteria.

\section{METHODS}

Organisms and growth. Methylosinus trichosporium Ов3в and Methylomonas albus BG8 (Whittenbury et al., 1970) were grown on methane, harvested in the exponential phase of growth and suspensions were prepared as described by Hubley, Mitton \& Wilkinson (I974).

Experiments with bacterial suspensions. Respiration studies used an oxygen electrode as described by Hubley et al. (1974). Routinely, $4.7 \mathrm{mg}$ dry wt bacteria were suspended in $2.7 \mathrm{ml} 20 \mathrm{mM}-\mathrm{Na}_{2} \mathrm{HPO}_{4} / \mathrm{KH}_{2} \mathrm{PO}_{4}$ buffer and oxygen uptake was recorded for $10 \mathrm{~min}$ at $30{ }^{\circ} \mathrm{C}$. For other incubations, a suspension of $47 \mathrm{mg}$ dry wt bacteria in $5 \mathrm{ml} 20 \mathrm{~mm}$-phosphate buffer in a $30 \mathrm{ml}$ round-bottomed Quickfit flask fitted with a rubber Suba-seal stopper was agitated on a Griffin and Tatlock Microid wrist-action shaker at $30{ }^{\circ} \mathrm{C}$.

Gas determination. Methane and $\mathrm{O}_{2}$ were measured using a Pye series $\mathrm{I}_{4}$ chromatograph with a katharometer detector and a $2.8 \mathrm{~m}$ silica gel column at $140{ }^{\circ} \mathrm{C}$ and $\mathrm{N}_{2}$ as carrier gas. Gas samples $(0.2 \mathrm{ml})$ were taken from the incubation flasks for analysis. Nitrous oxide was measured using the above system but at a temperature of $50^{\circ} \mathrm{C}$ (to ensure separation from $\mathrm{CO}_{2}$ ).

Nitrite and ammonia determinations. Samples $(0.2 \mathrm{ml})$ for determining nitrite or ammonia were taken from the incubation flasks or from the oxygen electrode vessel and added to $0.8 \mathrm{ml}$ phosphate buffer in a $\mathrm{I} \cdot 5 \mathrm{ml}$ microcentrifuge tube. Bacteria were sedimented by

* Present address: Yorkshire Water Authority (Southern Division), Castle Market Building, Exchange St, Sheffield SI IGB. 
centrifuging for $30 \mathrm{~s}$ in a Quickfit Micro-centrifuge and $0.5 \mathrm{ml}$ of the supernatant fluid was taken to determine either nitrite using the 'diazotization' method described by Nicholas \& Nason (1957), or ammonia using the method of Van Slyke \& Hiller (1933).

Materials. Methane, nitrogen, nitrous oxide and nitric oxide were obtained from The British Oxygen Co., Special Gases, London. Silica gel (80 to I00 mesh) was from Phase Separations, Queensferry, Clwyd.

Throughout this work 'ammonia' indicates the total concentration of $\mathrm{NH}_{3}+\mathrm{NH}_{4}{ }^{+}$.

\section{RESULTS}

\section{Ammonia oxidation}

A washed suspension of $M$. trichosporium in 20 mM-phosphate buffer $\mathrm{pH} 6.8$ took up oxygen, in the presence of Io mM-ammonia, at a rate of $4.1 \mathrm{nmol} \mathrm{\textrm {min } ^ { - 1 }}$ (mg dry wt bacteria) $)^{-1}$. This compares with $\mathrm{I} \cdot 3$ and 73 for the endogenous rate and the rate in the presence of 0.6 mM-methane respectively. Associated with the oxidation of ammonia was a stoicheiometric disappearance of ammonia and appearance of nitrite, both at rates which were linear over at least $100 \mathrm{~min}$. If the oxygen uptake in the presence of ammonia was corrected by substracting the endogenous level, the results were consistent with the stoicheiometry:

$$
\mathrm{NH}_{3}+\mathrm{I} \cdot 5 \mathrm{O}_{2} \rightarrow \mathrm{NO}_{2}{ }^{-}+\mathrm{H}^{+}+\mathrm{H}_{2} \mathrm{O}
$$

This is the same as that established for ammonia-oxidizing bacteria (Hofman \& Lees, 1953). Hydroxylamine was also oxidized to nitrite by methane-oxidizing bacteria, but at a higher rate than ammonia.

Effect of various compounds on ammonia oxidation. Both ammonia and hydroxylamine oxidation were subject to product inhibition by nitrite; nitrite production tailed off when the concentration of nitrite increased to 3 to $4 \mathrm{~mm}$. Furthermore, if $3 \mathrm{~mm}$-nitrite was initially included in the incubation mixture, then nitrite production from ammonia or hydroxylamine was inhibited by more than $90 \%$.

Formate stimulates the rate of oxidation of a number of substrates unable to support growth in methylobacteria, i.e. carbon monoxide (Ferenci, 1974), ethane (Thomson, 1974) and ethylene (Hubley, 1975). Formate had a similar effect on ammonia oxidation but in addition produced another stimulatory effect. The rate of nitrite production from ammonia in stationary phase bacteria was considerably slower than in exponential phase bacteria and also tended to decline at nitrite concentrations below those shown to be inhibitory. If formate was added at this stage of the incubation, nitrite production recommenced until inhibitory levels were reached.

Several other substrates (at $10 \mathrm{mM}$ ) were tested for their ability to stimulate ammonia oxidation. The rates of nitrite production $\left[\mathrm{nmol} \mathrm{min} \mathrm{m}^{-1}\left(\mathrm{mg}\right.\right.$ dry wt bacteria) $\left.{ }^{-1}\right]$ from ro mMammonia were: formate, 17.5; formaldehyde, 10.3; 3 -hydroxybutyrate, 9.6 ; pyruvate, $7 \cdot I$; acetate, $6 \cdot 5$; and methanol, $6 \cdot 0$. These compare with a value of $5 \cdot 8$ for ammonia alone. No stimulation of the rate of nitrite production from hydroxylamine was detected for any of these substrates.

Nitrite removal. Suspensions of bacteria grown with nitrate as the sole nitrogen source removed nitrite from the suspending medium when it was added initially and also after it had been produced from ammonia. The activity was stimulated by formate. This removal of nitrite is probably due to a functioning assimilatory nitrate pathway (see, for example, Payne, 1973). Probably related to this pathway was the occasional detection of nitrous oxide in the atmosphere over the incubation mixtures. The production of $\mathrm{N}_{2} \mathrm{O}$ from nitrite 
has been previously recorded for Nitrosomonas and a number of non-denitrifying heterotrophic bacteria and fungi (Yoshida \& Alexander, 1970; Ritchie \& Nicholas, 1972).

Effect of $\mathrm{pH}$ on ammonia oxidation and inhibition. Varying the $\mathrm{pH}$ had a far greater effect on ammonia oxidation than on methane oxidation by $M$. trichosporium; the rate of ammonia oxidation increased considerably with $\mathrm{pH}$. Inhibition of methane oxidation by ammonia increased as the $\mathrm{pH}$ increased. Thus, at $\mathrm{pH} 6 \cdot 0$ the rate of oxidation of ro mmammonia, as measured by oxygen uptake, was $0.8 \mathrm{nmol} \mathrm{min}^{-1}$ (mg dry wt bacteria) ${ }^{-1}$. This concentration of ammonia also inhibited oxidation of $0.5 \mathrm{~mm}$-methane by $6 \%$. At $\mathrm{pH} 8.0$ the rate of ammonia oxidation was $6.2 \mathrm{nmol} \mathrm{min}^{-1}(\mathrm{mg} \text { dry } \mathrm{wt})^{-1}$ and methane oxidation was inhibited by $59 \%$.

A possible explanation for the $\mathrm{pH}$ effects involving ammonia is that the active species is $\mathrm{NH}_{3}$ and not, as has been suggested, $\mathrm{NH}_{4}{ }^{+}$(Whittenbury et al., 1970). The proportion of $\mathrm{NH}_{3}$ to $\mathrm{NH}_{4}{ }^{+}$will decrease logarithmically with $\mathrm{pH}$ according to the Henderson-Hasselbalch relationship. Work by Suzuki, Dular \& Kwok (I974) has suggested that $\mathrm{NH}_{3}$ and not $\mathrm{NH}_{4}{ }^{+}$is the substrate for Nitrosomonas. These authors showed that an apparently large variation in $K_{\mathrm{m}}$ for ammonia with $\mathrm{pH}$ resolved to considerably closer values when calculated in terms of $\mathrm{NH}_{3}$ concentration.

\section{Kinetic analysis}

The behaviour of ammonia both as a substrate for oxidation and as an inhibitor of methane oxidation was investigated in terms of Michaelis-Menten kinetics. Harrison (I973) and Ferenci et al. (I975) reported some kinetic data for methane oxidation by methane-oxidizing bacteria using oxygen uptake as a measure of the initial rates. The work by Suzuki et al. (1974) on the kinetics of ammonia oxidation by Nitrosomonas also used oxygen uptake as a measure of the initial rates. With $M$. trichosporium, oxygen uptake provided a satisfactory measure of methane oxidation in the presence and absence of ammonia. However, the rates of oxygen uptake due to ammonia oxidation were too low (compared with endogenous rates) to obtain accurate data. The most satisfactory method for measuring rates of ammonia oxidation was by nitrite production.

Rates of methane oxidation, in the presence and absence of ammonia, were determined by following methane disappearance by gas-liquid chromatography. However, initial rates could not be obtained as accurately as with oxygen uptake, and methane concentrations in solution could only be calculated from concentrations in the gas phase. Despite these reservations, kinetic data obtained by both methods were in general agreement.

Ammonia as substrate. Using nitrite production as a measure of the rate of ammonia oxidation, good agreement with Michaelis-Menten kinetics was found. $K_{\mathrm{m}}$ values for ammonia were obtained at different $\mathrm{pH}$ values in the presence and absence of formate. The $K_{\mathrm{m}}$ for $\mathrm{NH}_{4}{ }^{+}$at $\mathrm{pH} 6.5$ was $4.1 \mathrm{mM}$, whereas at $\mathrm{pH} 7.5$ it was $0.6 \mathrm{mM}$. Recalculating $K_{\mathrm{m}}$ in terms of $\mathrm{NH}_{3}$ concentration gives essentially similar values of 7.4 and $10.4 \mu \mathrm{M}$ respectively. Repeating the determinations in the presence of formate gave a $K_{\mathrm{m}}$ value for $\mathrm{NH}_{4}{ }^{+}$ of $7 . \mathrm{I} \mathrm{mM}$ at $\mathrm{pH} 6.5$ and $0.4 \mathrm{mM}$ at $\mathrm{pH} 7.5$, resolving to values of 12.8 and $7.2 \mu \mathrm{M}-\mathrm{NH}_{3}$ respectively. The $\mathrm{NH}_{3}$ concentrations were calculated from the Henderson-Hasselbalch relationship assuming a $\mathrm{p} K$ value of 9.25 for the ionization $\mathrm{NH}_{3}+\mathrm{H}_{2} \mathrm{O} \rightleftharpoons \mathrm{NH}_{4}{ }^{+}+\mathrm{OH}^{-}$.

Ammonia as an inhibitor of methane oxidation. Using oxygen uptake to measure the initial rate of methane oxidation, good agreement was again obtained with MichaelisMenten kinetics, ammonia showing competitive inhibition of methane oxidation. At $\mathrm{pH}$ values between 6.0 and 8.0 the $K_{\mathrm{m}}$ for methane was 45 to $48 \mu \mathrm{M}$, whereas the $K_{\mathrm{i}}$ for $\mathrm{NH}_{4}{ }^{+}$ 


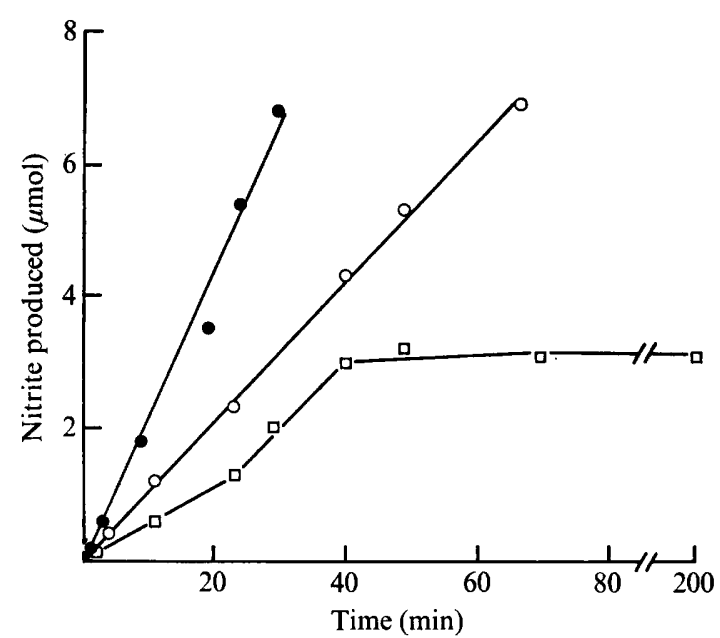

Fig. I. The effect of methane on nitrite production from ammonia. Incubations were carried out in $5 \mathrm{ml} 20$ mM-phosphate buffer pH 6.8 containing $47 \mathrm{mg}$ dry wt bacteria in $30 \mathrm{ml}$ round-bottomed flasks. Ammonia was at a final concentration of $10 \mathrm{~mm}$ and methane was added to the gas phase to give a concentration of $(\bigcirc) 8 \mu \mathrm{mol}$ and $(\square) 80 \mu \mathrm{mol}$. $\bigcirc$, No methane added.

decreased from $17.5 \mathrm{~mm}$ at $\mathrm{pH} 6.0$ to $0.2 \mathrm{~mm}$ at $\mathrm{pH} 8.0$. However, when recalculated in terms of $\mathrm{NH}_{3}$ concentration the $K_{1}$ values resolved to $9 \cdot 8$ and II $\cdot 2 \mu \mathrm{M}$ respectively.

\section{Effect of methane on ammonia oxidation}

The effect of methane on ammonia oxidation is complex, both stimulation and inhibition apparently being involved. Using nitrite production to measure the initial rates of ammonia oxidation, the effect of adding different volumes of methane to flasks is shown in Fig. I. Low levels of methane stimulated nitrite production, whereas high levels were inhibitory. The main effect was to halt nitrite production, indicating more complex interactions between ammonia and methane than are apparent in the initial reaction.

\section{Interactions of ammonia with Methylomonas albus $\mathrm{BG} 8$}

Limited studies were carried out with the type I methane-oxidizing bacterium Methylomonas albus BG8. Significant physiological differences have been observed between type I organisms and type II of which $M$. trichosporium is a representative (Whittenbury et al., 1970; Quayle, 1972; Whittenbury et al., 1975). Methylomonas albus behaved in an essentially similar manner to $M$. trichosporium in its interactions with ammonia, although detailed kinetic studies were not done. However, some differences were noted. Under similar conditions the degree of inhibition of methane oxidation was considerably less in the type I strain, as measured either by oxygen uptake or methane disappearance. In addition, rates of ammonia oxidation were considerably lower. Typical rates for nitrite production were about 0.5 and $4.0 \mathrm{nmol} \mathrm{min}^{-1}$ (mg dry wt bacteria) ${ }^{-1}$ for Methylomonas albus and M. trichosporium respectively. 


\section{DISCUSSION}

Our evidence suggests that $\mathrm{NH}_{3}$ rather than $\mathrm{NH}_{4}{ }^{+}$is involved in interactions with methylobacteria. The situation is thus similar to that in Nitrosomonas (Suzuki et al., 1974). In $M$. trichosporium the $K_{\mathrm{m}}$ value for $\mathrm{NH}_{3}$ as a substrate is the same as the $K_{\mathrm{i}}$ value when $\mathrm{NH}_{3}$ is acting as an inhibitor of methane oxidation, i.e. about Io $\mu \mathrm{M}$. This, together with the competitive nature of the inhibition, supports the argument that $\mathrm{NH}_{3}$ and methane are capable of binding to the same point of attachment in the methane oxygenase system.

The stimulation of ammonia-oxidizing activity by formate together with the known association of formate dehydrogenase with $\mathrm{NAD}^{+}$in methylobacteria (Harrington \& Kallio, 1960; Johnson \& Quayle, 1964) suggests that the reaction involves a mixed function oxidase as shown below:

$$
\mathrm{NH}_{3}+\mathrm{XH}_{2}+\mathrm{O}_{2} \rightarrow \mathrm{NH}_{2} \mathrm{OH}+\mathrm{X}+\mathrm{H}_{2} \mathrm{O}
$$

NADH acts as an electron donor in a similar reaction for methane oxidation in cellfree systems (Ribbons \& Michalover, 1970; Ferenci, 1974) but other electron donors are probably involved (Tonge et al., 1975). 3-Hydroxybutyrate also stimulates ammoniaoxidizing activity in $M$. trichosporium and the oxidation of this compound is linked to NAD (Thomson, O'Neill \& Wilkinson, 1976).

It has been suggested only relatively recently that the oxidation of ammonia by Nitrosomonas involves a mixed function oxygenase (Suzuki \& Kwok, I969). Suzuki (I974) has suggested that the terminal oxidation of nitroxyl $(\mathrm{NOH})$ provides the reducing equivalents for the oxygenase reaction and that the intermediate oxidation of $\mathrm{NH}_{2} \mathrm{OH}$ is the only energy-yielding step. The stimulation of the rate, and in some circumstances the extent, of ammonia oxidation by formate and other compounds might therefore suggest that a supply of endogenous reductant is utilized which may be replenished endogenously. However, the ratio of $\mathrm{O}_{2}: \mathrm{NH}_{3}$ in this case would be $2: \mathrm{I}$ and not the observed $\mathrm{I} \cdot 5: \mathrm{I}$, which suggests that reducing equivalents are being regenerated during ammonia oxidation.

We would like to thank British Petroleum Ltd for supporting this research and Eleanor Hogg for valuable technical assistance.

\section{REFERENCES}

FERENCI, T. (1974). Carbon monoxide-stimulated respiration in methane-utilising bacteria. FEBS Letters II, 54-97.

Ferenci, T., Strøm, T. \& Quayle, J. R. (1975). Oxidation of carbon monoxide and methane by Pseudomonas methanica. Journal of General Microbiology 91, 79-98.

Harrington, A. A. \& Kallio, R. E. (1960). Oxidation of methanol and formaldehyde by Pseudomonas methanica. Canadian Journal of Microbiology 6, $1-7$.

HARRISON, D. E. (I973). Studies on the affinity of methanol and methane-utilising bacteria for their carbon substrates. Journal of Applied Bacteriology 36, 99-108.

Hofman, T. \& Lees, H. (I953). The biochemistry of the nitrifying organisms. 4. The respiration and intermediary metabolism of Nitrosomonas. Biochemical Journal 54, 579-588.

Hooper, A. B. \& Terry, K. (1973). Specific inhibitors of ammonia oxidation in Nitrosomonas. Journal of Bacteriology II5, 480-485.

HubleY, J. H. (1975). Studies on the physiology of methane-utilising bacteria. Ph.D. thesis, University of Edinburgh.

Hubley, J. H., Mrtton, J. R. \& Wilkinson, J. F. (1974). The oxidation of carbon monoxide by methaneoxidising bacteria. Archives of Microbiology 95, 365-368.

Hubley, J. H., Thomson, A. W. \& Wilkinson, J. F. (I975). Specific inhibitors of methane oxidation in Methylosinus trichosporium. Archives of Microbiology 102, 199-202. 
Hutton, W. E. \& Zobell, C. E. (1949). Production of nitrite from ammonia by methane-oxidising bacteria. Journal of Bacteriology 65, $216-219$.

Johnson, P.A. \& QUAYLE, J. R. (I964). Microbial growth on $\mathrm{C}_{1}$-compounds. 6. Oxidation of methanol, formaldehyde and formate by methanol-grown Pseudomonas AMI. Biochemical Journal 93, 28I-290.

Nicholas, D. J. D. \& Nason, A. (1957). Determination of nitrate and nitrite. Methods in Enzymology 3 , $98 \mathrm{I}-984$.

Payne, W. J. (1973). Reduction of nitrogenous oxides by micro-organisms. Bacteriological Reviews 37, 409-452.

QUAYLE, J.R. (1972). The metabolism of single carbon compounds. Advances in Microbial Physiology 7 , II9-203.

Ribbons, D. W. \& Michalover, J. L. (1970). Methane oxidation by cell-free extracts of Methylococcus capsulatus. FEBS Letters II, $4 \mathrm{I}-44$.

Ritchie, G. A. F. \& Nicholas, D. J. D. (1972). Identification of the sources of nitrous oxide produced by oxidative and reductive processes in Nitrosomonas europaea. Biochemical Journal 126, I181-1 191.

SuZuKI, I. (1974). Mechanisms of inorganic oxidation and energy coupling. Annual Review of Microbiology 28, 85-IOI.

SuzukI, I. \& Kwok, S. C. (1969). Oxidation of ammonia by spheroplasts of Nitrosomonas europaea. Journal of Bacteriology 99, 897-898.

Suzuki, I., Dular, U. \& Kwok, S. C. (1974). Ammonia or ammonium ion as substrate for oxidation by Nitrosomonas europaea cells and extracts. Journal of Bacteriology 120, 556-558.

Thomson, A. W. (1974). Aspects of ethane metabolism in methylobacteria. Ph.D. thesis, University of Edinburgh.

Thomson, A. W., O’Neill, J. G. \& Wilkinson, J. F. (I976). Acetone production by methylobacteria. Archives of Microbiology rog, 243-246.

Tonge, G. M., Harrison, D. E. F., Knowles, C. J. \& Higgins, I. J. (I975). Properties and partial purification of the methane-oxidising enzyme system from Methylosinus trichosporium. FEBS Letters $\mathbf{5}^{8}$, 293-299.

VAN Slyke, D. D. \& Hiller, A. (I933). Determination of ammonia in blood. Journal of Biological Chemistry I02, 499-504.

Whittenbury, R., Phillips, K. C. \& Wilkinson, J. F. (1970). Enrichment, isolation and some general properties of methane-utilizing bacteria. Journal of General Microbiology 6r, 205-218.

Whittenbury, R., Dalton, H., Eccleston, M. \& Reed, H. L. (1975). The different types of methaneoxidising bacteria and some of their more unusual properties. In Microbial Growth on $C_{1}$-compounds, symposium, pp. I-9. Tokyo: The Society of Fermentation Technology, Japan.

WILKINSON, J. F. (197.I). Hydrocarbons as a source of single cell protein. Symposia of the Society for General Microbiology 21, I 5-46.

Yoshida, T. \& AlEXANDER, M. (1970). Nitrous oxide formation by Nitrosomonas europaea and heterotrophic micro-organisms. Proceedings. Soil Science Society of America 34, 880-882. 